Gramáticas de la (¿post?) violencia:

identidades, guerras, cuerpos y fronteras

\title{
"The sound of silenced voices": mobilizations, connections and demands in the investigation of slavery in Brazil
}

\author{
Márcia Leitão Pinheiro' \\ ' Universidade Estadual do Norte Flumiense Darcy Ribeiro, \\ Laboratório de Estudos da Sociedade Civil e do Estado, Rio de Janeiro/RJ, Brasil
}

\begin{abstract}
The Truth Commission (CV), a mechanism created to help manage the political transition from dictatorship to democracy in Brazil, has been appropriated by lawyers and Black movement organizations in Brazil. This appropriation has allowed them to criticize slavery and question Brazilian society about the long-term effects of forced labor and about the persistence of racism towards Afro-Brazilians. In the present article, I seek to highlight how Black scholars connect personal knowledge and experience to theory for the purpose of reshaping the concept of slavery. I focus on documents and videos related to this scenario, as well as data taken from interviews and the direct observation of the activities I have researched. Slavery is defined as a crime. It thus emerges as a power that is capable of endangering the present and future of Brazilian society. The specialists I analyze here ascribe to a conception of time related to the tension established with the historiography of slavery, as well as situations related to the disappearance of individuals. In this way, they seek to construct a memory of slavery and demand historical reparations.
\end{abstract}

Keywords: Truth Commission, Slavery, Crime, Historical Reparations. 


\section{"O som das vozes silenciadas": mobilizações, articulações e reivindicações na investigação da escravidão no Brasil}

\section{Resumo}

A Comissão da Verdade (CV), dispositivo de gestão de transição política, tem sido apropriada por advogadas/os e organizações do Movimento Negro no Brasil. Com isso, eles formam um cenário voltado a criticar a escravidão e a interrogar a sociedade brasileira acerca de seus efeitos e do racismo entre a população afro-brasileira. Ao focalizar documentos e vídeos relacionados a esse cenário, assim como material proveniente de entrevistas e observação direta das atividades pesquisadas, busco ressaltar como especialistas negros articulam conhecimentos e experiências pessoais e coletivas com o propósito de reelaborar a escravidão, redefinida como crime, e que aparece como força comprometedora do presente e do futuro da sociedade brasileira. Esses especialistas inscrevem uma concepção de tempo que tem a ver com a tensão estabelecida com a historiografia da escravidão e as situações relacionadas com o desaparecimento de pessoas de modo a construir uma memória da escravidão e reivindicar reparação histórica.

Palavras-chave: Comissão da Verdade, Escravidão, Crime, Reparação Histórica. 


\title{
"The sound of silenced voices": mobilizations, connections and demands in the investigation of slavery in Brazil
}

\author{
Márcia Leitão Pinheiro
}

One night in July 2015, the auditorium of the Rio de Janeiro section of the Brazilian Bar Association (Ordem dos Advogados do Brasil: OAB) hosted "Mothers of Acari - 25 years," an event that brought together a group of women and their family members in order to recall the struggle for justice that took place around the disappearance of several young men in 1990. The activity was organized by the Commission for Racial Equality and the Commission for Human Rights (both part of the OAB/RJ), the Network of Communities and Movements Against Violence, the Palmarino Circle, and the Unified Black Movement. The State Truth Commission on Black Slavery (connected to the OAB/RJ) also took part in the event.

The line of analysis around which the present article is structured focuses on the connections between legal specialists, the Black movement, and the appropriation these two groups have made of the Truth Commission (TC). This alliance has sought to investigate how the practice of repressing humans has, over the long term, affected Black populations in Rio de Janeiro and Brazil more widely. The alliance also seeks to create reparations for slavery and, in this context, attempts to construct a direct linkage between the past and the present.

The TC is a mechanism used to ease the political transition between dictatorship and democracy. It has been around since the 1980 s, created and maintained in relation to a set of subjects, practices, values, concepts, knowledges, categories, and discussions that belong to this historical context. These elements characterize the associations (such as commissions dedicated to reparations or reconciliations) that seek to confront violations of human rights and other forms (Hayner 2006; González Cueva 2011).

In general, the social scenario is directed towards promoting memory and combating the silencing and forgetting associated with political violence, civil war and dictatorships. In the face of accusations of abuse, of the use of excessive force, of suffering, of damage and of trauma - categories laid out in the TC's mandate -, symbolic and/or material reparative measures are demanded. These express questions about the past and offer up possibilities for the future. They can also promote connections between the involved parties, as well as corroborate demands for reparation (Jimeno 2010; Jelin 2014).

Given the existence of black associations that seek to investigate slavery and its consequences in the present and future, I use the notion of a "conflict management scenario" (hereafter referred to as the 'scenario') to refer to the actions and proposals of these groups (Castillejo 2014). These associations promote mobilizations, articulations and questioning in order to encourage the attainment of rights by nonhegemonic groups. In the scenario explored in the present article, they seek to denounce the forces that reinforce and sustain inequalities, while also highlighting how actions, feelings and values have current validity in social life. Ceremonies such as the homage cited above, speeches and practices are created by Black associations, which establish connections with those who have experienced cultural attacks, as well as human and material losses. 
In the article which follows, we shall see how the scenario in question was developed in order to demonstrate the persistence of the effects of slavery on Brazilian society and to explain how slavery still impacts on our conditions of existence today. We shall also look at the discursive texture of this scenario, which includes links between history and memory that make it possible to question the former by contrasting images of the latter, thus legitimizing the struggle for reparation rights.

This article is structured around an introduction, four subsections, and a conclusion. In the first part, I look at the formation of the National Truth Commission (NTC), which intensified the national debate regarding the investigation of abusive violence in Brazil. I also address the formation of the Black slavery research scene and its inclusion of Black movement organizations, as well as its transnational references. In the second section, I try to explain how Black slavery is elaborated as a crime, situating the composition of a narrative that questions official history. In the third part, I describe the "mothers of Acari, 25 years" event, looking at how its conception expresses an attempt to exceed the subjective and private by making connections between today's forced disappearance ${ }^{1}$ and the past of slavery. In the fourth section, I address how the homage to the mothers is concerned with ways of using the past as an intersection between history and memory in order to mark claims for reparation and an alternative future. In conclusion, I reflect on how the investigation of the truth of Black slavery marks the imagination of social life. This is linked to the exercise of technical knowledge and also to the work of remembrance of misfortunes, explaining how both of these things favor emotional closeness, as well as a specific conception of time.

In writing this article, I have employed documents, interviews and material from direct observation of the activities of the scenario under investigation, as well as videos of meetings. This makes it possible for me to dialogue with the formulations under investigation, especially those not defined by academic rules, such as ideas, values and actions (re)produced and lived by those who are part of the universe under investigation (Velho 2009). The challenge here is to understand how the CV device and its elements (which have obtained international and global media coverage) are appropriate as applied to the Brazilian reality. The complexity here, however, is not only in the intertwining of the global, national and local. Other dimensions are also intertwined (such as structural and subjective, impersonal and personal), especially in the participation of women and men who expose how they face situations that affect their everyday emotional conditions of existence. Verbal, written, video and artistic manifestations contribute to the understanding of actions as social and historical elements, which are elaborated, lived, felt and exposed by subjects who think about and confront hierarchies and what these produce in their lives (Jimeno 2012).

\section{Formation of the 'Black Slavery'Scenario}

The Truth Commission (TC) is a mechanism that has been adopted by countries in Latin America, the Caribbean and South Africa, among others. It is generally set up to mobilize the truth regarding the facts of authoritarian and profoundly unequal political regimes. Brazil joined the CT movement with the establishment of the National Truth Commission (NTC), created in 2011 and inaugurated in 2012, with the purpose of clarifying human rights violations and promoting the reconstruction of truth regarding the period stretching from 1946 to 1988 .

The NTC is part of the movement to promote the right to historical truth and memory by unveiling the violence practiced by the nation state. It expresses an atmosphere informed by the recognition of torture conducted by State agents. It removes this from its former unspeakable condition by highlighting

\footnotetext{
1 Forced disappearance is understood by the United Nations as an act that occurs with the aid or by order of a state employee. This has been a recurring practice in the world, motivating the creation, in 1992, of the Declaration Regarding the Protection of All People from Forced Disappearance (available at http://acnudh.org/wp-content/uploads/2010/12/Carta-desaparecimentos-PORTUGUES-FINAL.pdf consulted July 2017).
} 
testimony and documents making explicit the "structures, locations, institutions and circumstances related to the practice of human rights violations" as stated by Law 12.528/11. Before this initiative, the country maintained the "Dossier of Political Dead and Disappeared Since 1964." This was a list of those who had been politically assassinated or disappeared, the result of a non-state initiative including organizations such as the "Brazil: Never Again" movement, linked to the work of the Archdiocese of the State of São Paulo. There was also the "Special Commission on Political Deaths and Disappearances," created by Law 9.140/95, aimed at identifying those declared as disappeared and presumed dead in police records between 1961 and 1979 (Brasil 2014).

Following the birth of the NTC, the Black slavery research scenario was formed at the end of 2014. It had no connection to the National Executive Branch, but it quickly gained the support of the Brazilian Bar Association (OAB), founded in 1930. Different Brazilian states and municipalities started to employ some formation of this TC, ${ }^{2}$ generally linked to their sections of the Brazilian Bar Association (OAB) and guided by a methodology approved by the Federal Council of the Brazilian Bar Association (Cfoab) in November 2014. These various TC formations were thus committed to exposing the crime of Black slavery, pointing out its effects today, and holding the Brazilian State responsible.

In 2017, the Commission for Historical Reparations for Black People was created, also composed of Black lawyers (some of them former members of the Cvenb/RJ,) and counting on the participation of Black movement organizations operating in the state of Rio de Janeiro and in the country at large. ${ }^{3}$ This commission has the support of the Front of Black Jurists and the Lawyers' Assistance Office of the State of Rio de Janeiro (Caarj), founded in 1942. In general, the two commissions seek redress and to instigate discussions in society about the excessive use of force directed against the country's Black population.

The understanding that racism in Brazil is the result of the persistence of slavery is widespread in the scenario under investigation. The belief is that the impact of both on human lives, both in the past and now, must be revealed. It is also asserted that humanity in Brazil is differentiated into different social sectors according to skin color. ${ }^{4}$ At the center of this initiative is a confrontation with the myth of racial democracy, which presents Brazilian society as undivided and without conflicts based on race/color (Schwarcz 2012). It is widely argued and denounced in the scenario that this myth has effectively masked racism in Brazil and contributed to its harmful effects. To accomplish these goals, individual and collective knowledge and experiences have been linked together by Black organizations in order to compose activities and arguments.

Regarding the Black Slavery Truth Commission, Marcelo Dias, former president of the Rio de Janeiro branch, explained that its foundation occurred due to the mobilization of Black lawyers who had come together for a law conference in October 2014. These professionals spoke with the President of the National $\mathrm{OAB}$ at that time about the organization's support for the "Truth About the Dictatorship Commission," created in 2012 by the $\mathrm{OAB}$ to reveal the procedures of military justice during the dictatorship. They pointed out that the $O A B$ had still said nothing about Black slavery. According to my interviewee, the lawyers

\footnotetext{
2 Since 2015, some states and cities have created their own branches of the Cvenb: Espírito Santo, Rio de Janeiro, Minas Gerais, Bahia, Pará, São Paulo, Amazonas, Paraná and, finally, the cities of Santos, Campinas and Sorocaba.

3 Some organizations work at a national level while others are active on a state level. These include: the Movimento Negro Unificado (MNU), Movimento Nacional Quilombo Raça e Classe, Confederação Nacional dos Trabalhadores do Ramo Financeiro (Contrafcut), Coletivo de Entidades Negras (CEN), Agentes da Pastoral Negra (APNs), and Defensoria Pública do Estado do Rio de Janeiro.

4 Racism is a recurring category in the scenario under analysis and is often applied within the scenario to substantiate actions and claims. Racism can be understood as a form of thought or, even better, as a mechanism of population management, as Foucault points out (Mbembe 2003). Since the fifteenth century, racism has been based upon the creation of differences rooted in attributed characteristics and applied to create and sustain hierarchies of societies, groups and individuals. The "structure of Brazilian society" does not break with the "racial hierarchy" created by enslavement, being guided by a conception of human biological difference that organizes individuals into occupations and social places according to the color of their skin (Figueiredo \& Grosfoguel 2009: 224). The Brazilian Institute of Geography and Statistics (IBGE), for example, has presented a series of statistics for the years between 1995 and 2015 which show that those entering the formal labor market who identify themselves as black (men and women) earn lower wages than self-declared whites (also both men and women). With regards to unemployment, the rate is higher among Blacks (women and men) than among Whites. Available at http://www.ipea. gov.br/portal/index.php?option=com_content\&view=article\&id=29526. Consulted October 2017.
} 
then emphasized the validity of a commission to look into the matter. In that same year, the proposal was approved by Cfoab and, shortly thereafter, the National Commission on the Truth of Black Slavery in Brazil (Cvenb/Nacional) was created, being inaugurated in the following year. Subsequently, members of the OAB Equality Commission/RJ called for the creation of a Cvenb in the state of Rio de Janeiro.

With the emergence of the Cvenb/Nacional, the president of $\mathrm{Cfoab}$ sent an official letter to President Dilma Rousseff suggesting the creation of a committee dedicated to the topic within the scope of the National Executive. Despite the establishment of the NTC, Rousseff did not follow the letter's suggestion, even though the federal government was expected to adopt the bill, given that it took a new perspective on human rights abuses. According to a pronouncement made by Humberto Adami (president of the Cvenb/Nacional) at a hearing of the Human Rights and Minorities Commission of the Federal House of Representatives in October 2015, 5 a committee attached to the Executive or Legislative Branches would be able to raise questions that have historically been very little discussed. According to Adami, the work carried out would be aimed at understanding the "need for actions for the benefit of the afro-descendant population" in Brazil, such as "affirmative action as a principle of historical reparations." He noted that "the Afro-descendant population in Brazil lived and lives a horror story that has been on-going for more than 350 years" and that there is a "collective silence about this trauma within Brazilian society, which has translated into everyday racism. This has become so naturalized that a segment of the population cannot even see it." It could be said that Adami's proposal was an educational initiative, because the interpretations made, as well as the findings and actions regarding the past, would be aimed at expanding the sphere of debate and understanding about the effects of social and historical differences related to skin color (lighter or darker).

In the case of Rio de Janeiro, aside from the lawyers, several local organizations of the Black movement and others more oriented towards national affairs were integrated into the state commission, forming a strategic alliance (in the words of Marcelo Dias). These organizations promoted affirmative actions in higher education, the recognition of Afro-Brazilian religiosity and traditions, the defense of Quilombola territorial rights, and the production of research pertinent to the living conditions of the Black population. This diversified alliance could also count on unions, nuclei, and superintendencies linked to the Executive branches of certain municipalities, as well as class-based organizations involved in the promotion of racial equality and the fight against racism. ${ }^{6}$

With regards to the atmosphere in Brazil concerning the investigation of the truth, I asked Marcelo Dias about the formation of the research scenario related to slavery, as well as claims for reparations. He said that inspiration for this went well beyond the NTC, taking in the experiences of Caribbean countries which seek redress from the European nations that benefitted from slavery. Another model was eventually followed, however.

In the case of Cvenb, the Truth and Reconciliation Commission (TRC) established in South Africa in 1995 was the inspiration for the work carried out in Brazil. According to Dias, the peculiarity of the TRC lies in the negotiated transition from minority to majority rule in a country strained by race relations.

\footnotetext{
5 Available at http://www2.camara.leg.br/atividade-legislativa/comissoes/comissoes-permanentes/cdhm/videoArquivo?codSessao=54281\&codReuniao= 41296\#videoTitulo. Consulted July 2017.

6 The organizations of the Black movement involved with the Cvenb/RJ were: Quilombo Raça e Classe, Confederação Nacional Quilombola (Conaq), Agentes da Pastoral Negra (APNs), Movimento Negro Unificado (MNU), União de Negros e Negras pela Igualdade (Unegro), Centro de Tradições Afro-Brasileiras (Cetrab), Associação das Comunidades Quilombolas do Rio de Janeiro (Acquilerj), Instituto Pretos Novos (IPN), Conselho Municipal de Defesa dos Direitos do Negro (Comdedine), Renascença Clube, Sindicato dos Metroviários do Estado do Rio de Janeiro (Simerj), Agbara Dudu, Movimento Afro-Brasileiro de Cultura de Teresópolis (Mocabte), Associação Quilombola da Rasa, Superintendência de Políticas de Promoção da Igualdade Racial de São João de Meriti (Suppir-Meriti), Comissão da Igualdade Racial (OAB/RJ), Ordem dos Advogados do Brasil de Magé, Comissão da Igualdade Racial da OAB/Cabo Frio), Núcleo contra a Desigualdade Racial da Defensoria Pública (Nucora), Instituto Federal do Rio de Janeiro de Paulo de Frontin, Faculdades Paraíso /Grupo Lusófono and Viva Rio.
} 
With respect to this point of reference, the Cvenb/RJ partial report highlights the importance of the TRC in South Africa's “reconstruction process," which was conducted without revenge. It is presented as an example of "overcoming the past and rebuilding society." Its model, values, categories, procedures and knowledge have been central to the elaboration of slavery as an element in the formation of the commission that emerged in Brazil.

How the Black slavery research landscape links its concepts to the South African experience is demonstrated by the constant mentions of Nelson Mandela and his contribution to the process of rebuilding society. Desmond Tutu's cooperation has also been singled out as central to the promotion of social aggregation, in that he is understood to have created a way of facing the past of South African society without investing in reprisals.

The influence of the TRC can be seen when the partial report comments that the investigation of the truth of Black slavery must be related to brotherhood, to the recognition of the other, and to love, which is different from race and class hatred, widespread in Brazil since colonial times. Connecting the investigation of Black slavery with other values and emotions is part of an exercise in revealing the crimes that were practiced and the suffering imposed on the enslaved without individualizing accountability. The document and my conversations with the members of the scenario show the possibility of exposing and breaking with values, sensitivities and past practices. In order for this to occur, caution must be observed. Actions seen to be oriented by revenge or hatred cannot be encouraged. Above all, it is affirmed that knowledge about the practices of slavery can change coexistence by contributing to a "future of racial relations based upon love and friendship" (OAB/RJ 2015: 198).

The TRC model has been identified as successful. It has been followed in several countries as a means of promoting social security and as a way of overcoming the conflicts of the past. Reconciliation is tied to forgiveness, and both appear as elements supporting an argument about the future of society. It has been observed that, faced with the possibilities of revenge or social integration, the scenario of South African conflict management has favored a "global gospel of forgiveness and reconciliation," which has reached out to other locations around the globe. It is a discursive plot with strong religious and psychological references that establishes a remedial therapy for the violent damage caused in societies marked by racial divisions (Castillejo 2015). This has been a major inspiration for the initiatives created in Brazil.

\section{Reworking Slavery}

An interest in explaining the actions that shaped slavery and what made it possible to become such an effective force in Brazil has been part of the activities of those involved in the scenario under discussion here. Slavery is understood to be a criminal practice and, to this end, legal and historical knowledge is understood as important for the struggle against its effects. This can be seen in the documents the Crenb cites.

The documents produced in the scenario under analysis highlight national and international anti-racist measures: the Federal Constitution of Brazil (1988), which laid the groundwork for affirmative action, and the Racial Equality Statute (law 12.288/2010), aimed at defending individual, collective and diffuse ethnic rights. Both measures were created in Brazil as part of the struggle against discrimination and different forms of ethnic intolerance, both endemic in Brazil. At the international level, the selected documents emphasize the prevention and punishment of crimes, such as international conventions dealing with combating racism and xenophobia, or the declaration resulting from the Durban conference. Documents dealing with the "repression of the crime of genocide," "war crimes" and the "suppression and punishment of the crime of apartheid" are also listed. Another source is the statute that defines crimes that can be dealt 
with through the International Criminal Court: "Crimes of genocide, crimes against humanity, and war crimes." There is also the Report of the UN Expert Working Group which recognizes the "persistence of institutional racism in our country [Brazil]" (OAB 2015: 8).

The mobilization of several different organizations of the Black movement in a scenario that presumes to investigate the truth of Black slavery shows (as has been the case in other countries with Black populations) the proximity to and articulation with transnational questions and rhetorical/legal devices (Igreja \& Agudelo 2014) in the defense of local social and political rights. In this case, the Durban meeting can be understood as significant for the struggle for equality undertaken by the Black movements in defense of reparations for the Afro-descendant populations of the Caribbean and South America (Lao-Montes 2007, 2015). The use of national and international legal documents and rhetoric is a tactic forged for the interpretation of Black slavery, which is linked to the category genocide, as we shall see further on. Aside from laws, historical studies are also referenced, particularly those dealing with the slave trade in the Atlantic world and human submission to labor. From this perspective, the documents cited can be seen as basic references for the treatment of race relations as a field for intervention, for confronting racial hierarchies, and for the struggle against social and historical inequalities.

The scenario also criticizes what it calls legal and cordial slavery. This corresponds to a historiographical perspective which emerged at the beginning of the twentieth century and which portrayed slavery as a practice characterized by the harmonious coexistence of whites and blacks, slaves and enslavers. This view of history was heavily contested during the 1960 and 1970 by a view that emphasized the cruelty of slavery, the transformation of the captive into a 'thing,' and the portrayal of slave rebellions as a subjective expression of the denial of slavery itself. Later interpretations continued to challenge early twentieth century elaborations of slavery, but they also created other images of the enslaved, shifting the latter from the position of a 'thing' to that of a 'rebel captive' in opposition to the 'cruel master' who enslaved him, thus affirming the slave's humanity. From the 1980 s on, new explanations focused on the experiences and sociability of the enslaved, emphasizing their resistance and agency in the struggle for freedom. Finally, recent perspectives point to the creation of communities, strategies and the "reconstruction of autonomy" as ways of coping with slavocracy (Proença 2006).

In disagreement with the first two explanations, the scenario understands the enslaved as a subject of law, in view of the status of legal personhood ${ }^{7}$ recognized by the colonial secular and religious courts and which appears in the Cvenb/RJ's partial report. Allying itself with more recent historiographical interpretations, resistance has become the prominent ideal within the scenario, with revolts and the creation of social life in free spaces such as the quilombos being emphasized. Punished rebels appear as victims of practices of repression carried out by public authorities and by private individuals, both of which are seen to have been supported by the law of the times.

In addition to the anti-racist texts that criticize official history, there are studies on human trafficking and on the procedures of punishment - and execution -of the enslaved, especially those slaves involved in rebellions. Black slavery is thus redefined as a crime woven from a set of practices named as persecution, kidnapping, rape, homicide and extermination. In this way, the categories so framed allow one to point

\footnotetext{
7 I am grateful to John Burdick (Syracuse University) for pointing out the legal personhood category in American law, which makes it possible to understand the ambiguity of the condition of enslaved. On the one hand, slaves could be understood as property and merchandise but on the other hand, they could also receive legal treatment. Kopytoff's (2010) reflection on the cultural biography of things makes it possible to understand this peculiarity. The author observes that when captured, the slave is made into a non-person and transformed into merchandise. This condition does not wholly define the slave, however. The enslaved person also experiences new social relations that rehumanize him and thereby acquires another status, another condition that brings him closer to the status of a private individual - although one that can be traded. This understanding of the non-fixity of the status of the enslaved corroborates the understanding of the peculiarity of enslavement under the law.
} 
out how, over time, the submission of Africans and Blacks produced victims - the dead, the punished, those forcibly removed from their lands -, damage, and suffering, especially as experienced by children and young people.

In the speech of the members of the scenario, as well as in the texts produced within it, these acts that are seen as criminal are mobilized to elaborate the image of a Black body whipped across the Atlantic and into slavery. They contribute to emphasizing suffering as a relevant category in talking about the impact of such practices and how they expose the social forces that affect individual and collective experiences (Das 2008). The Brazilian State (in the form of its bureaucratic, political, juridical and police apparatus) is thus defined as being responsible for slavery and its effects - with the Catholic Church and the Portuguese Government seen as aiding and abetting parties. The State is always indicated and understood to be involved in the criminal and dehumanizing practices, and this is linked to the formulation of legal instruments or to non-compliance with them, and also to the receipt of taxes raised from the trafficking in human beings, who are then elevated to the condition of victims.

In looking at the scenario and the documents it highlights, it can be observed that there is a skillful articulation between anti-racist documents and international laws and acts related to the Atlantic traffic, enslavement and repression. The activities that constituted and sustained Black slavery (as a certain sort of historiography illustrates) are treated as genocide and as crimes against humanity. These categories are mobilized within an interpretation of a chain of practices and ideas. They are currently used to dramatically compose a view of what structurally molds Brazilian society, as well as various actions being carried out at the present time.

It should be emphasized that the category genocide has recurred in different configurations in order to reflect on state policies characterized by measures aimed at eliminating one group or another (Delrio \& Ramos 2011). Understood as an expression of colonialism, genocide is seen as the accentuation of the cogito: a world characterized by the elimination of or super-vigilance towards the Other: in this case, people of color (Maldonado-Torres 2007: 138).

This category has been historically present in the organizations of the Black movement, having been employed by Abdias do Nascimento - a critical thinker regarding racism and Brazilian society who is frequently referenced in the scenario - since the 197os. It has been employed to expose and denounce the physical and cultural destruction of Brazil's Black population. Along with the category, however, Abdias do Nascimento also presented a road map of actions that is currently being followed when talking about another future for the country (Nascimento 1978), as often happens in the scenario being described here.

In order to formulate slavery as genocide, the Black slavery research scenario is made up of members from diverse backgrounds: law, pedagogy/education, history, computer systems, political science, psychopedagogy, and the social sciences, for example. Possessed of specialized knowledge, these people may be considered Black specialists or 'Black intellectuals' (Santos 2011: 108), especially given that they are committed to the work of (re)interpreting Brazilian society and its racial specificities.

It is these members who place legal knowledge in dialogue with historical and sociological interpretations, as well as with local experiences and conflict management devices (such as the Truth Commission) and the categories all of these things produce. In this way, they seek to confront the practices of human submission, which are now (re)configured as criminal and not located in any given time period. The past and present practices of Brazilian society are thus woven together in a master narrative of injustice, linked to what is understood to be historical injury. This redefinition legitimizes the claims to rights. 


\section{A Homage to the Mothers: A Description}

Violence directed at Afro-Brazilian populations, especially against the young, is an issue that mobilizes organizations of the Black movement. It appears in tangible and explicit form in a homage addressed to a group of mothers whose children were victims of violence. The homage can be seen as related to the prevailing thoughtsof the investigation of the Black slavery scenario, this time translated into an affirmation regarding Black youth, as we shall see further on.

One night during the winter of 2015, the "Mothers of Acari, 25 years" event, which recounted the struggle of a group of women, took place in Rio de Janeiro. Few members of the original group, made up of seven mothers, were able to attend (due to illness or death) and report on what had happened in 1990. In that year, 11 young people were kidnapped and disappeared while they were visiting a place some kilometers from their homes in Acari, a district north of the city of Rio de Janeiro whose most notable claim to fame is its very low human development index (HDI). According to Amnesty International, members of the Military Police of the State of Rio de Janeiro wereinvolved in the case. In 1993, one of the members of the group of mothers investigating the case was killed while collecting information about her son's whereabouts. The representative of Amnesty International, present at the event in 2015, highlighted the State's noninvestigation of the occurrence, the lack of protection provided to the mothers of missing youths, and also how police "impunity in these cases" aided "police violence."

In the hall in front of the auditorium where the event took place, there was a clothesline from which hung photos and reports of the mothers activities. At one end, a sheet of cloth was used as a canvas on which the group's picture was hung and, below it, the names of the mothers and their children.

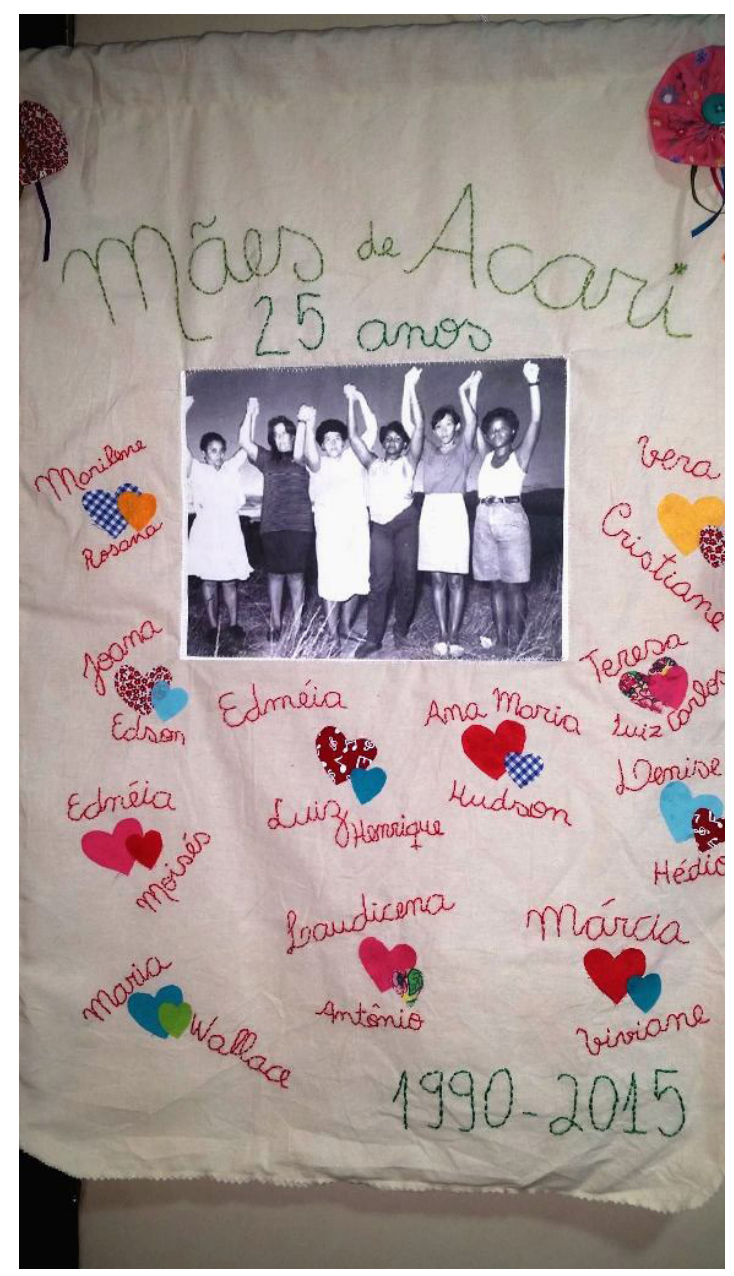


In the auditorium, another clothesline was used to display documents, photos of the youths, and their objects. This was an assemblage that spoke of life and its absence in such a way that each family's memory of the event was represented. It was a dense, emotional construction denouncing the acts of the State and its agents.

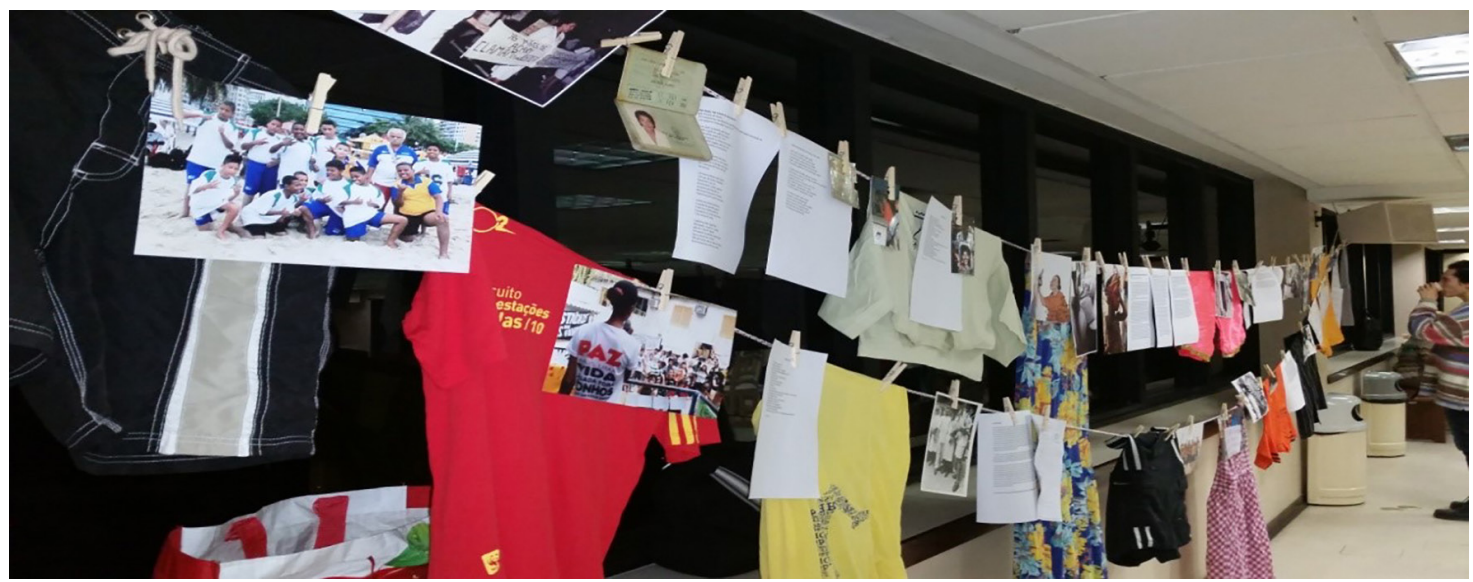

Present at the ceremony were the mothers and relatives of young people from other communities in Rio de Janeiro and cities such as Santos, in the state of São Paulo, who also experienced the disappearance of relatives. These people took part in the discussion table, in the center of which was a stylized Brazilian flag displaying the words Memory and Truth, Justice and Freedom. These categories go beyond the issues and actions of the local groups, taking into consideration initiatives that denounce torture and the disappearance of people ${ }^{8}$ involved in political activities, as the NTC report points out (Brazil 2014).

The places of the mothers who could not come to the event were taken by other relatives - often sons or daughters -who demonstrated that the group's mobilizationwould not end with the death or disabling of its original members. These relatives explained that they continued to gather information concerning the whereabouts of their sisters and brothers who had been subjected to the practice of forced disappearance. The family presence highlighted the movement of the mothers as something dynamic (Araújo 2007), affecting different generations who also develop and share tactics to denounce the absence of loved ones from their families and neighborhoods. Death certificates have still not been issued for these young men, a demand that the movement highlights even today and a problem often encountered by relatives who deal with disappearances.

Exposed to the suffering attendant upon the loss of children and siblings, the relatives reported that they constantly have to make these disappearances a subject of interest to the justice system and the police (Ferreira 2013). The event explicitly denounced State actions, highlighting family members claims to rights. It also positioned itself in the face of policies that act on human lives and allow intolerable situations to be understood as adequate and necessary in the maintenance of the moral order (Fassin 2014). The families testimony contributed evidence that State officials can act in a twilight zone between legality and nonlegality, making the rule of law uncertain (Das \& Poole 2008).

8 International Law treats the forced disappearance of people as a violation of human rights and a crime against humanity for which the State can be held responsible. The State is obligated to investigate these disappearances and pay indemnities to victims, as well as establish measures that prevent new cases from occurring (Citroni 2015). Forced disappearances have been a recurring feature throughout Latin American history and a particularly relevant element of the dictatorships that have been established in the region. Many Latin American regimes have even had specific branches of government whose purpose was to remove from social life those people understood as harmful to public order (Gatti 2011). In Brazil, forced disappearance of people by the police has taken place as part of a goal of "political repression.” It persists as a "practice of urban violence," together with "police violence" (Araújo 2016:47). 
The poster announcing the ceremony expresses a connection between color and violence, containing the photo of a Black woman related to the group of mothers. As a composition, its elaboration is not restricted to the singular nature of one face or one person's experience. On the contrary: the image calls out to other situations of loss allied to color; other faces, other women and mothers. Here we see something like a "simultaneity of faces" linked together by the power of expressing that which is common to all (Agamben 2015: 93).

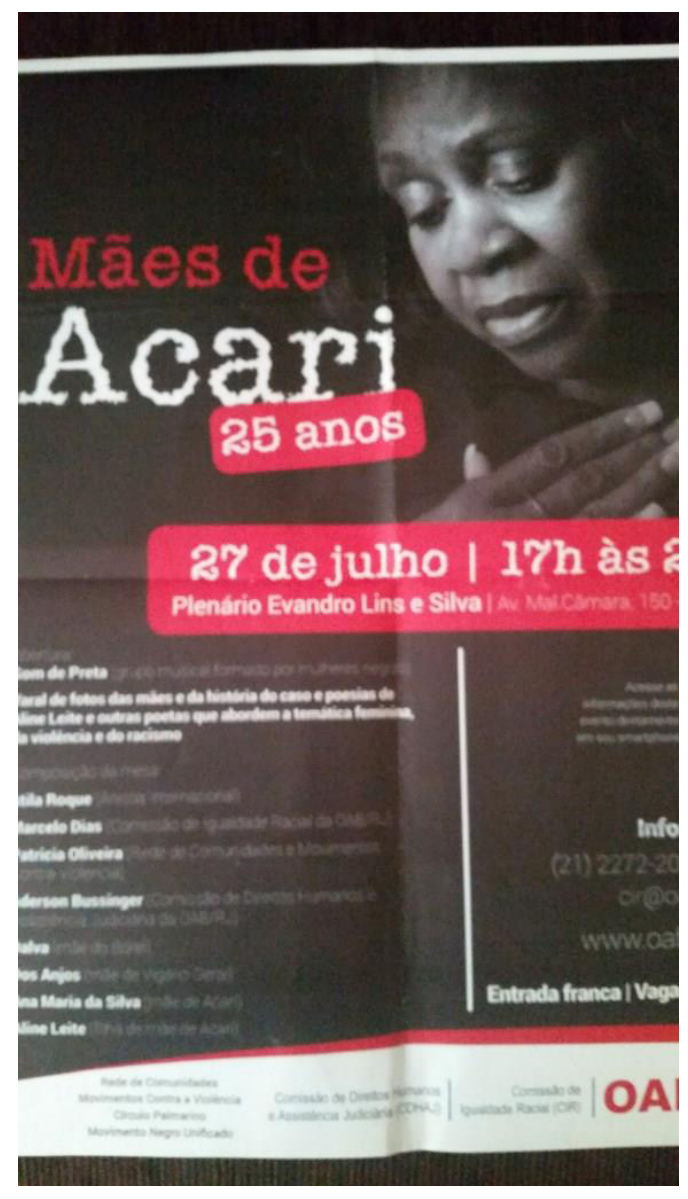

The link between the event and the issues surrounding the Black slavery research scenario was best expressed by the lawyers who spoke during the ceremony. In citing the killings that take place in the favelas of the city of Rio de Janeiro and in the country at large, Marcelo Dias, president of Cvenb/RJ at the time, said that the "history of our country is a history of violence, of extermination of our black youth." According to Dias, it is a "history of violence: 30 , ooo young people killed a year; 50,000 murders in the country." A lawyer who is also a member of the Human Rights Commission of the AOB/RJ noted that:

People forget that the crime of forced disappearance is not something that takes place or took place or only occurred in dictatorial states of exception. For those who are Black, for those who are Black in this country, this state of exception is a permanent thing. It is in your way in practically all spheres of life.

Both of these lawyers, faced with the question of the elimination of life as an expression of an entrenched hierarchy of color that is prevalent in Brazil, ended up by emphasizing the history of the nation as one characterized by the systematic deprivation of rights. Color and place of residence were identified by both as central elements in the definition of those most affected by the political practice of eliminating the Other. These two elements make up what can be understood as a "zone of indistinction" in which 
there is a lack of "legal protection" and the constant questioning of the right to life with the maintenance of procedures and apparatuses that are systematically geared to depriving people of this right. This is not something exclusive to "concentration camps": it exists in any place where laws and ordinances are suspended in order to control political life and the very existence of certain people. In such spaces, the police act in the interstices between violence and law, ignoring rules and turning Others into criminals (Agamben 2015: 44, 98, 99).

By recourse to the paradigm of the state of exception, the lawyers thus explained what is happening in the investigation of slavery scenario: references to the disappearance and extermination of young people, attributed to police forces, are constant and related to trafficking of humans for slavery. The members of the scenario constantly emphasize that younger men were preferred for slavery because they could better resist the Atlantic crossing and fetched higher prices when put up for sale.

\section{History, Memory and Reparations}

The arguments of the Black slavery research scenario are based on a defense of the reconstruction of the "relationship between the old and the new," which depends on the present confronting the past in order for the harmonization of diversity and pluralism to take place. This task is to be achieved by opening ourselves to "the sound of the voices that have been silenced throughout history," according to the Cvenb/RJ partial report (OAB/RJ 2015: 130). As Wilson Prudente (prosecutor of the Public Labor Ministry and member of the Cvenb/RJ) stressed during a public hearing, Brazilian society "lives with a past a mentality... lives still under the haunting [presence] of the slave regime... Brazilian society has never faced the problem of its past." 9

Prudente's words refer to the current debate in the scenario, which emphasizes history and memory as two necessary factors for the explanation and confrontation of situations that affect the physical and cultural existence of Black Brazilians. This view permeates the partial report, public hearings, meetings and seminars held by Black associations, public bodies and universities. At these moments, many topics that are considered to be relevant are highlighted, especially in the public hearings that have been held in different cities throughout the Metropolitan Region and the state of Rio de Janeiro (OAB/RJ 2015).

In addition to violence against Black families and youth, the theme of territorial exclusion has also appeared at these moments, referring to the quilombola communities that have for struggled years to obtain recognition and the rights to the land they occupy. Another recurrent theme has been religious intolerance: the verbal, physical and symbolic violence that has been part of the historical treatment given by political and scientific institutions to cultural manifestations of African origin. The religious issue has recurred in public hearings and has resulted in a meeting of representatives of African-origin religions (held at the Center for Afro-Brazilian Traditions in October 2015) in order to discuss statutes related to the rights of these religious practices (OAB/RJ 2015).

With these questions, the scenario's confrontation between history and memory adds its central arguments to local struggles. This position is disseminated through texts, transmitted by social networks, evidenced in testimonies given to the written press, demonstrated by participation in television programs and public hearings. In all of these forums, the tension between history and memory is constantly stressed by the members of the commissions.

The reflection on slavery contained in the Cvenb/RJ's partial report shows a particular understanding of written history, understood as a falsification given that it has caused the "oppressed Afro-descendants to have their eyes clouded by stories told to them in the school, at all levels, and in the cultural industry,

9 Available at https://www.youtube.com/user/tvcamarario. Consulted July 2017. 
everywhere" (p.129). This critical view understands history as the reconstruction of an event - often related to power - as an exercise of knowing-in-order-to-say, which keeps the Other at arm's length as history speaks for him, especially when defining what should be '“understood' and what must be forgotten in order to obtain the representation of present intelligibility" (Certeau 2011: 13,14,15).

As a counterpoint to the sort of historiography that speaks about and for Blacks, the members of the scenario propose the rescue of memory. They argue that much needs to be recovered with the statements and information that people can provide and that places can contain in order to elaborate and expose another interpretation of the past and present. In 2015, therefore, visits were made to the quilombola communities and conversations were held with their residents. A tour of old plantations was also conducted to collect evidence or material evidence, as Humberto Adami, president of the Cvenb/Nacional, remarks in his talks about the objects used in the punishment of slaves and the conditions of existence in the slave barracks. The Cvenb/RJ also paid a visit to the archives of the diocese of the city of Nova Iguaçu in the Baixada Fluminense, a region of Rio de Janeiro state. Here, books recording the baptism, marriage and death of slaves and free Blacks were found, as well as records regarding instruments intended for use in the torture of slaves. A visit was also paid to the Black Museum, an institution under the care of the Brotherhood of Our Lady of the Rosary and St. Benedict of the Black Men, located in Rio de Janeiro's city center. Here, instruments used to force the submission of human beings were examined and recorded. A meeting was also held with the General Command of the Military Police of the State of Rio de Janeiro and also with the Museum of the Military Police in order to obtain access to the police archives and to carry out research for the Cvenb/RJ (OAB/RJ 2015).

The issues central to the scenario, especially in the cities that hosted public hearings and visits, are part of a set of activities related to the findings on the theme of slavery and aimed to build greater coherence between information and materials that carry traces of the past (Halbwachs 2006). How this is linked to specialized knowledge corroborates a past use that operates in two planes: showinghow historical interpretation conceals tensions and, at the same time, composing an elaboration of the past that explains the violence and the racial inequality that we find today embedded in Brazilian society. This use of the past is not only intended to highlight the memory of conflict (which has to do with the elaboration of some given event), but also the conflict of memories (which involves oppositions and disputes between interpretations of the past) when one speaks about the practice of forced submission (N'Garoné 2012). The conflict of memories thus established relates to the combativeness of groups that position themselves in society in order to question history, the consensus surrounding it and the present democracy in the struggle for their rights (Macé 2012).

Memory is closely related to political action and the Truth Commission (TC) also takes advantage of this fact, employing voices that deal with the 'outrages' and 'suffering' experienced in the past. In this way, the past is located as close to the present moment and this gives sustenance to the policies of reparations (Bevernage 2016, 2012). This is a situation that involves the admission of the abuses that were practiced and their effects. It can result in material and/or symbolic indemnities that express the recognition of the damage done and that aim to promote the restoration of social relations. Reparation can thus be seen as a corrective mechanism related to a group's 'self-consciousness,' producing rites that are conducive to integration or social reconciliation. Such a moment obviously contains critiques of the elements that led to the state of crisis - the symbolic dimension in this sense- and, as a corollary, reconciliation measures must be evaluated to see if they have indeed been successful and how success was forged (Turner 2008).

The practice of linking events located in different moments in time has characterized the demands and struggles of the Black population of Brazil; it is enough to mention the mobilization in favor of affirmative action and, as emphasized above, the struggle for reparations. In this case, the focus is not on financial 
support as compensation for slavery, but on the elaboration and consolidation of public policies that are understood as resources which can transform the material and living conditions of the favelas, for example. This is the main point raised when members of the scenario talk about "overcoming the past and projecting a future." For the members of this movement, society must become aware of the effects of what was once practiced in order to establish a less unequal and more diversity-oriented country in the future, as is stated in the partial report (OAB/RJ 2015: 1, 130, 198).

The challenge of looking to the past for the promotion of equality and justice should be undertaken in a spirit of love and friendship. In this way, the perspective of a new Brazilian society will win out, configured by values and feelings that do not trigger instability but that can compose another sort of democracy, one which is understood as not yet widespread in our society, although it has long been imagined as a racial democracy.

The projection of a new society has been part of the activities of the TC and this has also occurred in Colombia, a society characterized by armed conflict that pervades daily life and citizenship. In the latter country, the commission for "truth and reconciliation" has reflected on the differentiation and inequalities within Colombian society. Claims for reparations are part of a field of tensions that involves technical, political and social knowledge and that results in effective measures considered able to transform everyday life and the way in which this and society are imagined. The Colombian case shows how the TC device is connected to thinking about the nation in the context of expectations of a 'new reality.' This implies ways of relating past and future (Castillejo 2015: 17, 19).

\section{Conclusion}

In the present article, I have sought to approach a scenario that is based on a critique of the conflicts in Brazilian society, pointing to the participation of organizations of the Black movement and Black lawyers in this scenario and their creation of a legal basis for the redefinition of slavery. We have seen how this scenario was formed and how the National Truth Commission (NTC) reinforced a local climate regarding the treatment of history and memory in order to reveal conflicts and human rights violations that have occurred in institutional spaces. The South African commission was also identified as a reference for action in a society marked by racial tensions, presenting procedures and perspectives for the closer integration of the said society.

We verified that the analyzed scenario aims to create an approach to Brazilian reality that emphasizes historical reparations. This is done by denouncing temporal links between practices of violence directed against the country's Black population. Characteristically, this asserts that the current form of democracy in Brazil is limited and also limits life. These claims, in turn, challenge the self-image of Brazilian society, since they affirm that multiracialism and multiculturalism are not yet widespread in the nation.

The central point of this scenario is based on the explication of the longevity of Black slavery and the strength of racism as structural elements in Brazilian society. As we have seen, this scenario references the CTR developed in South Africa, which ended up revealing a set of violations that affected individuals and their bodies. The individualist cut of this approach has, however, led to criticisms, as has the Commission on Human Rights, created in 2005. For this commission (CHR), the CTR did not emphasize the links between violations, colonialism and apartheid - related to practices, values and political dispositions - and thus contributing little to exposing the structural relations that guided racialized violations (Ross 2006). 
In order to fulfill its objective, the work carried out in the Brazilian scenario has, in turn, gone through stages consisting of tasks, questions and concepts that are closely linked in order to compose images about the past, emphasizing practices, values and feelings that situate Black slavery as something harmful. Slavery and its temporal effects are, however, set beyond individual reach, since it is argued that the present and the future are tied together when it comes to racism and the inequalities affecting Brazil's Black population.

One of the stages of this process consists in resorting to historiography and memory and relates to the criticism directed against historiography, given that, for members of the scenario, history can hide or mute voices in its efforts to affirm a certain narrative. Black experts have emphasized memory over history and seek to create coherence between the arguments, statements, locations, objects and documents that they have collected in aid of this project. Memory is thus woven into politics and seen as a motivator of reflection and willingness to act (N'Garoné 2012, Jelin 2014). Memory makes explicit another understanding of facts and of how they influence daily existence.

This appeal to memory contributes to stripping away the idea of cordial slavery (which underpins Brazil's racial democracy narrative), pointing out that slavery was full of dehumanizing practices and episodes of cruelty. Confronting history with memory - while simultaneously relying on historiography to chart out black resistance - members of the scenario indicate that these cruel practices cannot be considered to be an individual or private affair, given that they were not the product of one or a few masters' decisions. The practices that characterized the slavery system in Brazil are linked to State policy based on the annihilation of Otherness.

Not surprisingly, considering the 'social sensitivity' regarding blackness in Brazilian society (Schwarcz 2012: 54) and which marks the actions highlighted here, racism and genocide have been central elements in the scenario's discourses regarding slavery. The questions raised strongly refer to State practices, since the State manifestly does not protect all lives and its discrimination in this sense can be understood as related to the incorporation of race in the policies developed by the State. It is thus the application of technique, bureaucracy and State mechanisms that mark the State's institutional performance, which is characterized by the destitution of the Other of rights and basic humanity (Mbembe 2003).

Another step linked to this work of historical criticism can be seen in the ceremony honoring the mothers of the young people who were disappeared in Acari more than two decades ago. The clothes, photos and documents on display during this event emphasize that these youths once had a bodily existence whose continuity is uncertain (Gatti 2011).

This event also showed how the scenario situates the damage of slavery in time, linking the past to damaged or missing bodies today. Here the personal (silences, crying, testimonies and personal objects, which are all part of another way of being in public (Gatti 2017) merged with the collective in exposing the social disorder that disappearance introduces, particularly in the daily lives of Black families who have lamented human loss over time. During the ceremony, it was explained how groups can process that which is lived as misfortune, as pain that reaches into their existence (Das 2008).

The cases exposed during the ceremony gave density to the legal arguments made by members of the scenario. How these two things were related contributed to connecting together the mothers, other relatives of the disappeared, and those present at the ceremony. This group then exposed and reflected upon the brutality of State practices, confronting the imaginary of the State as protector and guarantor of rights and life (Das \& Poole 2008). We can thus say that this arrangement reaffirms a sense of 'emotional community,' given that such a community can be seen as aimed at denouncing the effects of violence and mobilizing for recognition of affronts to life, in favor of dignity and claims for reparations (Jimeno 2010; Jimeno, Varela \& Castillo 2011). 
Finally, the work carried out in the scenario analyzed here cooperates in creating a public space shared by subaltern groups. It points to a conception of time not based on unrepeatable and linear phases, but rather on the contact between the past and the present with the reflection on the persistence of social inequalities and their effects. With this understanding of temporality, the reflection on crises, dramas, feelings and accusations, as well as agendas for action, can be understood as a process of correction and reconciliation (Turner 2008), contributing to our imagination of the future. This, however, also seems to rupture with time, with sensitivities, with past values and practices, pointing towards a very common tension in truth commissions. Taking into consideration the scenario researched here, one might ask what initiatives will be designed in Brazil in order to change the set of inequalities and violence currently reigning in our society, creating instead an image of a future characterized by non-violence? Here the South African and Colombian cases may again contribute to our understanding of what is happening in Brazil. It has been pointed out that non-repetition - a basic element necessary for the success of reconciliation and reparation - does not only include a move to interrupting violence and injustice. It is also something much more complex. It must contain a dialectic between rupture and continuity and it is therefore important to observe when both situations can be presented. That is, we need to evaluate the implemented actions, what they affect or fail to do, and what they do or do not expose in terms of the structure of inequality. Only in this way can we understand when and how rupture and continuity manifest themselves (Castillejo 2015: 19).

Received: September $29^{\text {th }}, 2017$

Approved: January $6^{\text {th }}, 2018$

Translation: Thaddeus Gregory Blanchette

Revision: David Rodgers

* This article is a result of the research project “Tempo da 'verdade': categorias e articulações na investigação da escravidão e seus efeitos na atualidade no estado do Rio de Janeiro" (Time and Truth: Categories and Connections in the Investigation of Slavery and its Effects on Current Life in the State of Rio de Janeiro"), begun in 2015. I would like to thank the Instituto de Estudos Sociais e Políticos (IESP) of the Universidade do Estado do Rio de Janeiro (UERJ) for the support given to me during my research for this article. I am also grateful to the anonymous evaluators for their valuable suggestions. Finally, I would like to thank Fátima Cecchetto (Fiocruz) and Patrícia Farias (UFRJ) for their comments on the first version of this article. 


\section{References}

AGAMBEM, Giorgio. 2015. Meios sem fim: notas sobre a política. Belo Horizonte: Autêntica Editora.

ARAÚJO, Fábio Alves. 2016. “'Não tem corpo, não tem crime’: notas socioantropológicas sobre o ato de fazer desaparecer corpos." Horizontes Antropológicos, 22(46): 37-64.

. 2007. Do luto à luta: a experiência das Mães de Acari. Master’s Dissertation, Programa de Pós-Graduação em Sociologia e Antropologia - Rio de Janeiro.

BEVERNAGE. Berber. 2016. "Un pasado desde el presente. La historia y la política del tiempo en la justicia transicional." 2016. Revista Colombiana de Educación, 71: 25-52.

2012. History, memory and state-sponsored violence: time and justice. New York: Routledge.

BRASIL. 2014. Relatório da Comissão Nacional da Verdade. Brasília: CNV.

. 2010. Lei no 12.288, publicada no Diário Oficial da União, 20 jul. 2010, p.o1.

. 1988. Constituição da República Federativa do Brasil, publicado no Diário Oficial da União, 05 out.

1988, no 191 - A.

CASTILLEJO, Alejandro. 2015. La imaginación social del porvenir: reflexiones sobre Colombia y el prospecto de una Comisión de la Verdad. Buenos Aires: Clacso.

. 2014. "La localizacion del daño: etnografia, espacio y confesión en el escenario colombiano".

Horizontes Antropológicos, 20(42): 213-236.

CERTEAU, Michel de. 2011. A escrita da história. Rio de Janeiro: Ed. Forense.

CITRONI, Gabriella. 2015. "La Desaparición Forzada en México: Entre Avances y Retos Pendientes." FICHL Policy Brief Series, 39: 1-4.

DAS, Veena. 2008. "Lenguaje y cuerpo: transacciones en la construcción del dolor." In: Francisco A. Ortega (ed.), Veena Das: sujetos del dolor, agentes de dignidad. Bogotá: Universidad Nacional de Colombia. Facultad de Ciencias Humanas: Pontificia Universidad Javeriana. Instituto Pensar. pp. 343-374.

.; POOLE, Deborah. 2008. "El estado y sus márgenes: etnografias comparadas". Cuadernos de Antropología Social, 27: 19-52.

DELRIO, Walter; RAMOS, Ana. 2011. "Genocidio como categoría analítica: memoria social y marcos analiticos."CORPUS. Archivos Virtuales de la Alteridad Americana, 1(2): 1-7.

FASSIN, Didier. 2014. "Compaixão e repressão: a economia moral das políticas de imigração na França."Ponto Urbe, 15: 1-22.

FERREIRA, Letícia. 2013. "Pesquisar e participar da formulação de uma causa pública: notas etnográficas sobre o desaparecimento de pessoas no Brasil." Campos - Revista de Antropologia Social, 14(1/2):195-2015.

FIGUEIREDO, Ângela; GROSFOGUEL, Ramón. 2009. "Racismo à brasileira ou racismo sem racistas: colonialidade e a negação do racismo no espaço universitário." Sociedade e Cultura, 12(2): 223-234.

GATTI, Gabriel. 2017. "Presentación: um mundo de víctimas". In: Gabriel Gatti (ed.), Um mundo de víctimas. Barcelona: Anthropos Editorial. pp. 5-23.

. 2011. "El lenguaje de las víctimas: silencios (ruidosos) y parodias (serias) para hablar (sin hacerlo) de la desaparición forzada de personas." Universitas humanística, 72: 89-109.

GONZÁLEZ CUEVA, Eduardo. 2011. "Até onde vão as Comissões da Verdade”. In: Félix Reátegui (ed.), Justiça de transição: manual para a América Latina. Brasília: Comissão de Anistia, Ministério da Justiça; New York: International Center for Transitional Justice. pp. 339-355.

HALBWACHS, Maurice. 2006. A memória coletiva. São Paulo: Centauro.

HAYNER, Priscila B. 2006. "Truth commissions: an schematic overview."International Review of the Red Cross, 88(862): 295-310.

IGREJA, Rebecca; AGUDELO, Carlos. 2014. "Afrodescendentes na América Latina e Caribe: novos caminhos, novas perspectivas em um contexto global multicultural." Revista de Estudos e Pesquisas sobre as Américas, 08(01): 13-28. 
JELIN, Elizabeth. 2014. "Memoria y democracia. Una relación incierta." Revista Mexicana de Ciencias Políticas $y$ Sociales, $\operatorname{LIX}(221): 225-242$.

JIMENO, Myriam. 2012. "Introducción: el método antropológico en el contexto local.” In: Myriam Jimeno; Sandra Liliana Murillo; Marco Julián Martínez (eds.), Etnografías contemporáneas: trabajo de campo. Bogotá: Universidad Nacional de Colombia. Facultad de Ciencias Humanas. Centro de Estudios Sociales (CES), pp.9-18.

. 2010. "Emoções e política: a vítima e a construção de comunidades emocionais." Mana. Estudos de Antropologia Social, 16(1): 99-121.

JIMENO, Myriam; VARELA, Daniel; CASTILLO, Ángela. 2011. "Experiencias de violencia: etnografía e recomposición social en Colombia." Sociedade e Cultura, 14(2): 275-285.

KOPYTOFF, Igor. 2010. "A biografia cultural das coisas: a mercantilização como processo.” In: Arjun Appadurai (ed.), A vida social das coisas: as mercadorias sob uma perspectiva cultural. Niterói: EDUFF. pp. 89-121.

LAO-MONTES, Agustín. 2015. "Movimientos sociales afrolatinoamericanos". América Latina en Movimiento," 501:5-8.

. 2007. "Sin justicia étnico-racial no hay paz: las afro-reparaciones en perspectiva histórico-mundial." In: Claudia Mosquera; Luiz Cláudio Barcelos (eds.), Afro-repaciones: memorias de la esclavitud y justicia reparativa para negros, afrocolombianos e raizales. Bogotá: Universidad Nacional de Colombia. pp.132-153.

MACÉ, Jean-François. 2012. "Los conflictos de memoria en la España postfranquista (1976-2010) entre políticas de la memoria y memorias de la política." Bulletin hispanique, 114(2): 749-774.

MALDONADO-TORRES, Nelson. 2007. "Sobre la colonialidad del ser: contribucionesal desarrollo de un concepto.” In: Santiago Castro-Gómez; Ramón Grosfoguel (eds.), El giro decolonial: reflexiones para una diversidad epistémica más allá del capitalismo global. Bogotá: Siglo del Hombre Editores; Universidad Central, Instituto de Estudios Sociales Contemporáneos y Pontificia Universidad Javeriana, Instituto Pensar. pp. 127-168.

MBEMBE, Achille. 2003. "Necropolitics." Public Culture, 15(1): 11-40.

NASCIMENTO, Abdias. 1978. O genocídio do negro brasileiro. Rio de Janeiro: Paz e Terra.

N’GARONÉ, Rémadjie. 2012. "Mémoires et conflits en Guadeloupe. Formes anthropologiques du conflit". Revue Internationale d'Anthropologie Culturelle \& Sociale, 1: 33-55.

OAB. 2015. Metodologia da Comissão Nacional da Verdade sobre a Escravidão Negra no Brasil. Brasília/ DF.

OAB/RJ. 2015. Relatório da Comissão Estadual da Verdade da Escravidão Negra. Rio de Janeiro: OAB/RJ.

PROENÇA, Wander de Lara. 2006. "Escravidão no Brasil: Debates Historiográficos Contemporâneos.”Anais eletrônicos da XXIV Semana de História: "Pensando o Brasil no Centenário de Caio Prado Júnior."

ROSS, Fiona. 2006. "La elaboración de una Memoria Nacional: la Comisión de Verdad y Reconciliación de Sudáfrica." Cuadernos de Antropología Social, 24: 51-68.

SANTOS, Sales Augusto dos. 2011. "A metamorfose em militantes negros em negros intelectuais." Revista Mosaico, 5(III):102-125.

SCHWARCZ, Lilia. 2012. "Do preto, do branco e do amarelo: sobre o mito nacional de um Brasil (bem) mestiçado." Ciência e Cultura, 64(1): 48-55.

TURNER, Victor. 2008. Dramas, campos e metáforas: ação simbólica na sociedade humana. Niterói: Editora da Universidade Federal Fluminense.

VELHO, Gilberto. 2009. "Antropologia urbana: encontro de tradições e novas perspectivas." Sociologia, problemas e práticas, 59: 11-18. 


\section{Websites consulted}

http://acnudh.org

https://anistia.org.br

www2.camara.leg.br

http://www.cnv.gov.br

http://www.ipea.gov.br

https://www.youtube.com

Márcia Leitão Pinheiro

Associate Professor at the Laboratório de Estudos da Sociedade Civil e do Estado of the Universidade Estadual do Norte Flumiense Darcy Ribeiro- Lesce/UENF, Rio de Janeiro, RJ, Brazil.

https://orcid.org/oooo-0001-6695-4585

E-mail:marcialpx@hotmail.com 